\title{
Corrigendum: Malaria and the liver: immunological hide-and-seek or subversion of immunity from within?
}

\author{
Patrick Bertolino * and David G. Bowen \\ Liver Immunology Group, Centenary Institute and AW Morrow Gastroenterology and Liver Centre, University of Sydney and \\ Royal Prince Alfred Hospital, Sydney, NSW, Australia
}

Keywords: LSEC, malaria, sporozoites, CD8 T cells, tolerance

\section{A corrigendum on}

Malaria and the liver: immunological hide-and-seek or subversion of immunity from within? by Bertolino, P., and Bowen, D. G. (2015). Front. Microbiol. 6:41. doi: 10.3389/fmicb.2015.00041

In the original article on page 4 , there is an error in the following sentence:

"[...] Liver sinusoidal endothelial cells are efficient scavenger cells strategically located in the

OPEN ACCESS

Edited by:

Ute Frevert,

New York University School of Medicine, USA

Reviewed by:

Xun Suo,

China Agricultural University, China Hajime Hisaeda,

Gunma University, Japan

${ }^{*}$ Correspondence:

Patrick Bertolino,

p.bertolino@centenary.org.au

Specialty section: This article was submitted to Microbial Immunology, a section of the journal

Frontiers in Microbiology

Received: 31 March 2015 Accepted: 28 April 2015 Published: 13 May 2015

Citation: Bertolino $P$ and Bowen DG (2015) Corrigendum: Malaria and the liver:

immunological hide-and-seek or subversion of immunity from within?

Front. Microbiol. 6:460.

doi: 10.3389/fmicb.2015.00460 sinusoids and able to clear low-density lipoprotein (LDL) and capture particulate antigens and immune complexes circulating via the blood and deliver them to hepatocytes (Sorensen et al., 2012). This uptake is mediated by mannose receptor, and has been shown to be more efficient than that mediated by KC, suggesting that LSEC specialize in this function. [...]"

The correct sentence is:

“[...] Liver sinusoidal endothelial cells are efficient scavenger cells strategically located in the sinusoids, and able to clear oxidised or acetylated low-density lipoprotein (LDL) and capture small particles $(<200 \mathrm{~nm})$ circulating via the blood (Sorensen et al., 2012). This uptake is mediated by several receptors and has been shown to be more efficient than that mediated by KC, suggesting that LSEC specialize in this function. [...]"

\section{Funding}

This work was supported by the NHMRC Australia (Program grant 571408).

\section{References}

Sorensen, K. K., McCourt, P., Berg, T., Crossley, C., Le Couteur, D., Wake, K., et al. (2012). The scavenger endothelial cell: a new player in homeostasis and immunity. Am. J. Physiol. Regul. Integr. Comp. Physiol. 303, R1217-R1230. doi: 10.1152/ajpregu.00686.2011

Conflict of Interest Statement: The authors declare that the research was conducted in the absence of any commercial or financial relationships that could be construed as a potential conflict of interest.

Copyright $\odot 2015$ Bertolino and Bowen. This is an open-access article distributed under the terms of the Creative Commons Attribution License (CC BY). The use, distribution or reproduction in other forums is permitted, provided the original author(s) or licensor are credited and that the original publication in this journal is cited, in accordance with accepted academic practice. No use, distribution or reproduction is permitted which does not comply with these terms. 